\title{
PENANGANAN MULTIKOLINEARITAS DENGAN MENGGUNAKAN ANALISIS REGRESI KOMPONEN UTAMA PADA KASUS IMPOR BERAS DI PROVINSI SULUT
}

\author{
Mega Sriningsih $^{1)}$, Djoni Hatidja $^{1^{*}}$, Jantje D. Prang $^{1)}$ \\ ${ }^{1)}$ Program Studi Matematika, FMIPA, Universitas Sam Ratulangi Manado \\ ${ }^{*}$ Coresponding author: dhatidja@gmail.com
}

\begin{abstract}
ABSTRAK
Multikolinearitas adalah suatu kondisi dimana terjadi korelasi antara variabel bebas atau antar variabel bebas tidak bersifat saling bebas. Besaran yang dapat digunakan untuk mendeteksi adanya multikolinearitas adalah faktor inflasi ragam (Variance Inflation Factor / VIF). Tujuan dari penelitian ini yakni untuk mengetahui cara mengatasi multikolinearitas, menentukan model persamaan regresi komponen utama, dan mengetahui variabel-variabel yang mempengaruhi impor beras di SULUT. Penelitian menggunakan data impor beras di Sulawesi Utara pada tahun 20062015. Data akan di analisis menggunakan analisis regresi komponen utama. Analisis regresi komponen utama dapat mengatasi masalah multikolinearitas pada data impor beras di Sulawesi Utara dimana terlihat nilai VIF pada regresi komponen utama bernilai satu untuk semua variabel komponen utama. Berdasarkan hasil analisis regresi komponen utama diperoleh model $\widehat{\mathrm{Y}}=$ $48258,1804+0,006739247 X_{1}-0,92939626 X_{2}-0,06475365 X_{3}-0,38551398 X_{4}+$ $0,0001233267 X_{5}+5,365936 X_{6}+0,0006384361 X_{7}+0.0005029473 X_{8}-3,25379897 X_{9}+$ $0,01069348 X_{10}$ dan koefisien determinasi $\left(R^{2}\right)=90,36 \%$ dan nilai $\left(R_{\text {adj }}\right)=85,53 \%$. Semua variabel yaitu Produksi beras Sulawesi Utara $\left(X_{1}\right)$, stok beras di Sulawesi Utara $\left(X_{2}\right)$, luas panen padi Sulawesi utara $\left(X_{3}\right)$, penerimaan beras dari dalam negeri sulawesi utara $\left(X_{4}\right)$, devisa impor paid pada bea dan cukai Bitung $\left(X_{5}\right)$, produk domestik regional bruto atas dasar harga berlaku menurut lapangan usaha di Sulawesi Utara $\left(X_{6}\right)$, pendapatan pajak daerah Sulawesi Utara $\left(X_{7}\right)$, penggunaan devisa impor unpaid pada bea dan cukai Bitung $\left(X_{8}\right)$, kurs $\left(X_{9}\right)$, dan jumlah penduduk Sulawesi Utara $\left(X_{10}\right)$ mempengaruhi impor beras di SULUT (Y).
\end{abstract}

Kata Kunci : Multikolinearitas, Regresi Komponen Utama, Variance Inflation Factor (VIF), Impor Beras.

\section{MULTICOLLINEARITY HANDLING USING PRINCIPAL COMPONENTS REFRESSION ON IMPORTED RICE CASE IN NORTH SULAWESI PROVINCE}

\begin{abstract}
Multicolinearity is a condition where there is correlation between independent variables or between independent variables that are not mutually free. The quantity that can be used to detect the presence of multicollinearity is Variance Inflation Factor (VIF). The purpose of this research is to determine the equation model of regression principal component, and to know the variables that influence on rice import in SULUT. The study used data of rice imports in North Sulawesi in 2006-2015. The data will be analyzed using regression analysis of principal components. Regression analysis of principal component can overcome the problem of multicollinearity in rice import data in North Sulawesi where seen VIF value at regression of principal component is one for all principal component variable. Based on the analysis results of regression principal component, has obtained the model $\mathrm{Y}=48258,1804+0,006739247 \mathrm{X}_{1}-0,92939626 \mathrm{X}_{2}-$ $0,06475365 X_{3}-0,38551398 X_{4}+0,0001233267 X_{5}+5,365936 X_{6}+0,0006384361 X_{7}+$ $0.0005029473 X_{8}-3,25379897 X_{9}+0,01069348 X_{10}$ and coefficient of determination $\left(R^{2}\right)=$ $90,36 \%$ and value $\left(\mathrm{R}_{\mathrm{adj}}\right)=85,53 \%$. All variables i.e North Sulawesi rice production $\left(\mathrm{X}_{1}\right)$, rice stock in North Sulawesi $\left(\mathrm{X}_{2}\right)$, harvested area of North Sulawesi $\left(\mathrm{X}_{3}\right)$, domestic rice revenues from north Sulawesi $\left(\mathrm{X}_{4}\right)$, import duty paid of Bitung's custom duty and excise $\left(\mathrm{X}_{5}\right)$, gross regional domestic product of current prices by business field in North Sulawesi $\left(\mathrm{X}_{6}\right)$, North Sulawesi tax
\end{abstract}


revenues $\left(\mathrm{X}_{7}\right)$, unpaid import duties on customs duty and excise $\left(\mathrm{X}_{8}\right)$, exchange rate $\left(\mathrm{X}_{9}\right)$, and population North Sulawesi $\left(\mathrm{X}_{10}\right)$ affects the import of rice in SULUT $(\mathrm{Y})$.

Keywords : Multicolinearity, Principal Component Regression, Variance Inflation Factor (VIF), Rice Import.

\section{PENDAHULUAN}

Kurang lebih 95 persen dari jumlah penduduk Indonesia mengkonsumsi beras setiap tahunnya. Selain karena faktor tradisi dan kebiasaan dari penduduk, berbagai kandungan di dalam beras seperti glukosa, protein, mineral dan vitamin yang dapat meningkatkan metabolisme tubuh, menjadikan beras sebagai makanan layak konsumsi.

Pada hasil penelitian terkadang tidak sengaja dijumpai data multikolinier dimana variabel bebas saling berhubungan, sehingga menjadi masalah yang cukup serius dalam melakukan analisis data penelitian. Apabila terdapat multikolinearitas diantara variabel bebas maka penaksiran parameter model regresi dengan menggunakan metode kuadrat terkecil akan menghasilkan penaksir yang tak bias. Pendeteksian multikolinearitas dapat dilakukan secara informal salah satunya dengan koefisien korelasi linear antar variabel bebas maupun dengan cara formal dengan faktor inflasi ragam.

Istilah multikolinearitas pertamatama ditemukan oleh Ragnar Frisch pada tahun 1934 yang berarti terdapat hubungan antara variabel bebas. Terjadinya multikolinearitas diantara variabel-variabel bebas dapat mengakibatkan konsekuensi penting bagi penafsiran dan penggunaan model regresi dugaan, karena dapat menyebabkan tanda dari koefisien regresi menjadi salah atau keputusan menjadi tidak signifikan (Sembiring, 1995).

Analisis komponen utama merupakan teknik statistik yang digunakan untuk menjelaskan struktur variansi-kovarians dari sekumpulan variabel melalui beberapa variabel baru, dimana variabel baru ini saling bebas dan merupakan kombinasi linear dari variabel asal. Analisis komponen utama pada dasarnya bertujuan untuk menyederhanakan peubah yang diamati dengan cara menyusutkan (mereduksi) dimensinya. Hal ini dilakukan dengan jalan menghilangkan korelasi di antara peubah melalui transformasi peubah asal kepeubah baru (merupakan kombinasi linear dari peubahpeubah asal) yang tidak saling berkorelasi.

Sebelumnya penelitian oleh Wohon, et. al., (2017) dengan judul "Penentuan model regresi terbaik menggunakan metode stepwise" menggunakan data impor beras di Sulawesi Utara tahun 2006-2015. Dalam penelitian ini terdapat masalah multikolinearitas pada data impor beras di Sulawesi Utara. Oleh karena itu dengan menggunakan regresi komponen utama pada penelitian ini kita dapat mengatasi data yang terdapat masalah multikolinearitas.

Berdasarkan uraian diatas maka tujuan dari penelitian ini yakni: 1) mengetahui cara mengatasi multikolinearitas; 2) menentukan model persamaan regresi komponen utama; dan 3) mengetahui variable-variabel yang mempengaruhi impor beras di SULUT.

\section{TINJAUAN PUSTAKA}

\section{Multikolinearitas}

Multikolinearitas adalah suatu kondisi dimana terjadi korelasi antara variabel bebas atau antar variabel bebas tidak bersifat saling bebas. Besaran (quality) yang dapat digunakan untuk mendeteksi adanya multikolinearitas adalah faktor inflasi ragam (Variance Inflation Factor / VIF). VIF digunakan sebagai kriteria untuk mendeteksi multikolinearitas pada regresi linier yang melibatkan lebih dari dua variabel bebas. Nilai VIF lebih besar dari 10 mengidentifikasi adanya masalah multikolinearitas yang serius (Ryan, 1997). VIF untuk koefisien regresi-j diidentifikasikan sebagai berikut:

$$
V I F_{j}=\frac{1}{1-R_{j}^{2}}
$$

Dengan : $R_{j}^{2}$ adalah koefisien determinasi antara $X_{j}$ dengan variable bebas lainnya pada persamaan / model dugaan ; dimana $\mathrm{j}=$ $1,2, \ldots, \mathrm{p}$. 


\section{Analisis Komponen Utama}

Analisis komponen utama merupakan teknik statistik yang dapat digunakan untuk menjelaskan struktur variansi-kovariansi dari sekumpulan variabel baru dimana variabel baru ini saling bebas, dan merupakan kombinasi linier dari variabel asal. Selanjutnya variabel baru ini dinamakan komponen utama (principal component). Secara umum tujuan dari analisis komponen utama adalah mereduksi dimensi data dan untuk kebutuhan interpretasi.

\section{Kriteria Pemilihan Komponen Utama}

Salah satu tujuan dari analisis komponen utama adalah mereduksi dimensi data asal semula terdapat $p$ variabel bebas menjadi $k$ komponen utama (dimana $k<p$ ). Kriteria pemilihan $k$ yaitu :

Menurut (Suryanto, 1988) banyaknya komponen utama yang digunakan dalam membentuk model ditentukan dengan mengambil akar ciri yang lebih besar dari satu. Kriteria ini digunakan apabila analisis faktor didasarkan pada matriks korelasi.

Tidak semua komponen utama dapat digunakan. (Morrison, 1978) menyarankan agar memilih komponen-komponen utama sampai komponen-komponen utama tersebut mempunyai keragaman kumulatif $75 \%$. Namun sebagian ahli menyarankan agar memilih komponen utama yang mempunyai akar ciri (nilai eigen) lebih dari satu karena jika akar ciri kurang dari satu keragaman data yang dapat diterangkan kecil sekali.

\section{Uji Keberartian Model Regresi Komponen Utama}

Keberartian model regresi komponen utama dapat diuji dengan hipotesis uji sebagai berikut:

$$
\begin{aligned}
& H_{0}: \partial_{k}=0\left(\begin{array}{c}
\text { model regresi secara } \\
\text { keseluruhan tidak berarti }
\end{array}\right) \\
& H_{1}: \partial_{k} \neq 0\left(\begin{array}{c}
\text { model regresi secara } \\
\text { keseluruhan berarti }
\end{array}\right)
\end{aligned}
$$

Tabel 1. ANOVA

\begin{tabular}{|l|l|l|l|}
\hline $\begin{array}{r}\text { Sumber } \\
\text { Variasi }\end{array}$ & DB & JK & \multicolumn{1}{|c|}{ KT } \\
\hline Regresi & $\mathrm{k}$ & $\hat{\beta}^{\prime} X^{\prime} Y-\frac{\left(\sum Y\right)^{2}}{n}$ & $\begin{array}{l}\text { SS } \\
\text { (Regresi)/ } \\
\mathrm{k}\end{array}$ \\
\hline Error & $\mathrm{n}-\mathrm{k}-1$ & $\begin{array}{l}\mathrm{SS} \text { (Total)- } \\
\mathrm{SS} \text { (Regresi) }\end{array}$ & $\begin{array}{l}\text { SS } \\
\text { (Residu)/n } \\
-\mathrm{k}-1\end{array}$ \\
\hline Total & $\mathrm{n}-1$ & $Y^{\prime} Y-\frac{\left(\sum Y\right)^{2}}{n}$ & $\begin{array}{l}\text { SS } \\
\text { (Regresi) } \\
+ \text { SS } \\
\text { (Residu) }\end{array}$ \\
\hline
\end{tabular}

$F$ hitung $=\frac{M S(\text { Regresi })}{M S(\text { Error })}$

Kriteria Uji : Tolak $H_{0}$ jika $F_{\text {hitung }}>F_{\alpha}$. (Antono et al. 2014)

\section{Analisis signifikansi koefisien regresi komponen utama}

Uji signifikansi koefisien terhadap masing-masing variabel baku dilakukan untuk melihat terdapat pengaruh atau tidak dari masing-masing variabel baku (Mariana, 2013).

Langkah pertama yaitu menentukan nilai $S^{*^{2}}$ terlebih dahulu menggunakan rumus:

$$
S^{* 2}=\frac{S^{2}}{\sum(y-\bar{y})^{2}}
$$

Dimana: $S^{2}$ adalah kuadrat tengah eror; $\sum(y-\bar{y})^{2}$ adalah jumlah kuadrat total.

Selanjutnya akan diperoleh ragam koefisien regresi utama dengan rumus : $\operatorname{Var}\left(\gamma_{n}\right)=S^{* 2} \sum_{g=1}^{m} \frac{\alpha_{i j}}{\lambda_{i}} ; i=1,2, \ldots, p ; j=1,2, \ldots, m$

Pengujian signifikansi terhadap koefisien regresi secara parsial untuk mengetahui pengaruh dari setiap peubah bebas digunakan uji t, yaitu:

$$
t\left(\gamma_{1}\right)=\frac{\gamma_{1}}{S\left(\gamma_{1}\right)}
$$

\section{METODE PENELITIAN}

\section{Waktu dan Tempat Penelitian}

Penelitian berlangsung selama 4 bulan yaitu pada bulan September 2017 sampai bulan Januari 2018, dari persiapan sampai penyusunan proposal penelitian. Penelitian dilaksanakan di Fakultas 
Matematika dan Ilmu Pengetahuan Alam Universitas Sam Ratulangi Manado.

\section{Data dan Variabel}

Data dalam penelitian ini menggunakan data sekunder yang diperoleh dari Badan Pusat Statistik Provinsi Sulawesi Utara. Data yang diambil berupa data untaian waktu (time series) dari tahun 2006-2015.

\section{Metode Analisis Data}

Metode analisis yang digunakan untuk mencapai tujuan adalah dengan menggunakan Analisis Komponen Utama untuk memperbaiki data yang ada dengan langkah-langkah sebagai berikut:

1. Mendefenisikan variabel terikat $Y$ dan variabel bebas $X$. Variabel terikat $Y$ adalah Impor beras di Sulawesi Utara dan variabel $X$ adalah faktor-faktor yang mempengaruhi impor beras di Sulawesi Utara.

2. Melakukan analisis regresi untuk menentukan model regresi.

3. Melakukan uji asumsi klasik yaitu uji multikolinearitas dengan cara melihat nilai-nilai VIF dan nilai korelasi antar variabel bebas.

4. Menangani multikolinearitas yang terjadi pada data menggunakan metode PCA (Principal Component Analysis) / Analisis Komponen Utama.

Tahapan-tahapan Analisis Komponen Utama :
a. Membakukan peubah bebas $X$ menjadi $Z$.
b. Mencari akar ciri dan vektor ciri dari matriks korelasi.
c. Menghitung skor komponen utama dari vektor ciri.

5. Lakukan regresi dengan komponen utama terpilih yaitu dengan meregresikan peubah respon $Y$ terhadap skor komponen utama $W$.

6. Mentransformasi balik peubah baku $Z$ menjadi $X$.

7. Melakukan uji keberartian model regresi komponen utama.

8. Menghitung standar error untuk masingmasing koefisien regresi, pengujian koefisien regresi dan melakukan pengujian dengan menggunakan uji-t.
Berikut adalah persamaan regresi dalam bentuk peubah asal $X$ setelah di transformasi dari bentuk baku :

$$
Y=\alpha_{0}+\alpha_{1} X_{1}+\alpha_{2} X_{2}+\cdots+\alpha_{k} X_{k}
$$

\section{HASIL DAN PEMBAHASAN}

\section{Analisis Regresi}

Regression Analysis: y versus x1, x2, x3, x4, x5, x8, x9, x10

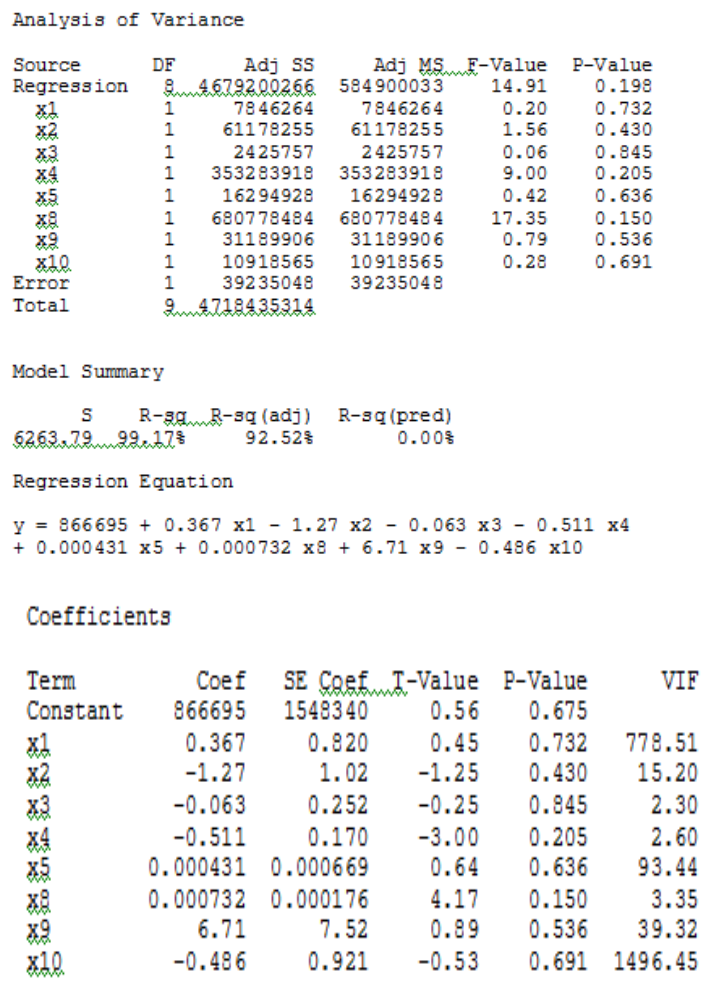

Dari hasil minitab diatas dapat diketahui jika persamaan regresinya adalah $\mathrm{Y}$ $=866695+0.367 \mathrm{X} 1-1.27 \mathrm{X} 2-0.063 \mathrm{X} 3-$ $0.511 \mathrm{X} 4+0.000431 \mathrm{X} 5+0.000732 \mathrm{X} 8$ $+6.71 \times 9-0.486 \times 10$; dengan $\mathrm{R}-\mathrm{Sq}=$ $99,17 \%$ dan $\mathrm{R}-\mathrm{Sq}(\operatorname{adj})=92,52 \%$.

\section{Uji Multikolinearitas}

Untuk menguji ada tidaknya multikolinearitas, kita dapat menggunakan nilai VIF (Variance Inflation Factor). Jika nilai VIF melebihi 10 maka hal tersebut menunjukan bahwa multikolinearitas adalah masalah yang pasti terjadi antar variabel bebas. Dengan bantuan minitab, kita dapat memperoleh nilai VIF pada hasil regresi linear berganda.

Berdasarkan hasil analisis di atas, terlihat bahwa terdapat beberapa variabel 
yang memiliki nilai VIF lebih dari 10 yaitu variabel $X_{1}, X_{2}, X_{5}, X_{9}$, dan $X_{10}$. Oleh karena itu, dapat dipastikan bahwa ada masalah multikolinearitas antar vatiabel bebas pada data.

\section{Analisis Komponen Utama}

Berikut merupakan tahapan-tahapan dalam analisis komponen utama :

\section{Pembakuan peubah bebas $X$ menjadi $Z$}

Langkah pertama pada analisis regresi komponen utama adalah mentransformasikan variabel-variabel bebas ke dalam variabel baku $Z$, langkah ini di lakukan pada Ms. Excel dengan menggunakan rumus

$$
Z_{n}=\frac{X_{n}-\bar{X}_{n}}{s t d e v}
$$

\section{Mencari akar ciri dan vector ciri dari matriks $\mathbf{R}$}

Langkah berikutnya pada analisis regresi komponen utama dalam menangani multikolinearitas yaitu mencari akar ciri dan vektor ciri dari matriks $\mathrm{R} /$ matriks korelasi. Untuk mendapatkan komponen utama $W$ beberapa ahli menyarankan agar memilih komponen utama yang mempunyai akar ciri lebih dari satu agar keragaman data yang diterangkan tidak kecil.

Dan hasil uji terlihat bahwa komponen PC1, PC2 dan PC3 yang memiliki nilai eigen lebih dari 1 yaitu 6,1063, 1,6093 dan 1,0700. Komponen PC1 ini dapat menjelaskan $61,1 \%$ keragaman data, PC2 dapat menjelaskan 16,1\% keragaman data dan PC3 dapat menjelaskan $10,7 \%$ keragaman data. Sehingga nilai untuk komponen dapat dihitung dengan melihat nilai koefisien untuk masing-masing variabel sebagai berikut :

$W 1=0,391 \mathrm{Z1}+0,216 \mathrm{Z2}+0,310 \mathrm{Z3}+0,100 \mathrm{Z4}$ $+0,349 Z 5+0,393 Z 6+0,394 Z 7-0,024 Z 8+$ $0,324 Z 9+0,398 Z 10$

$W 2=0,076 Z 1-0,473 Z 2+0,005 Z 3-0.533 Z 4+$ $0,241 Z 5+0,150 Z 6+0,077 Z 7-0,024 Z 8-$ $0,253 Z 9+0,116 Z 10$

$W 3=-0,046 Z 1-0,351 \mathrm{Z2}+0,079 \mathrm{Z3}-0,559 \mathrm{Z4}$ $-0,222 Z 5+0,102 Z 6+0,089 Z 7-0,624 Z 8+$ $0,312 Z 9+0,029 Z 10$
Tabel 2. Vektor Ciri

\begin{tabular}{|c|c|c|c|c|c|c|c|c|c|}
\hline 0,391 & 0,076 & $-0,046$ & $-0,028$ & $-0,128$ & 0,191 & 0,538 & $-0,449$ & 0,147 & $-0,522$ \\
\hline 0,216 & $-0,473$ & $-0,351$ & 0,172 & 0,715 & 0,163 & 0,149 & 0,115 & $-0,036$ & 0,043 \\
\hline 0,310 & 0,005 & 0,079 & $-0,891$ & 0,216 & $-0,190$ & $-0,108$ & 0,079 & $-0,038$ & $-0,037$ \\
\hline 0,100 & $-0,533$ & $-0,559$ & $-0,130$ & $-0,590$ & $-0,109$ & $-0,080$ & $-0,016$ & $-0,068$ & 0,070 \\
\hline 0,349 & 0,241 & $-0,222$ & 0,119 & 0,046 & 0,332 & $-0,755$ & $-0,215$ & 0,075 & $-0,152$ \\
\hline 0,393 & 0,150 & 0,102 & 0,079 & $-0,081$ & 0,117 & 0,144 & $-0,179$ & $-0,719$ & 0,466 \\
\hline 0,394 & 0,077 & 0,089 & 0,207 & $-0,171$ & $-0,069$ & 0,016 & 0,764 & $-0,159$ & $-0,381$ \\
\hline$-0,024$ & 0,568 & $-0,624$ & 0,061 & 0,139 & $-0,492$ & 0,144 & 0,009 & $-0,023$ & 0,036 \\
\hline 0,324 & $-0,253$ & 0,312 & 0,301 & 0,072 & $-0,711$ & $-0,185$ & $-0,296$ & 0,097 & $-0,026$ \\
\hline 0,398 & 0,116 & 0,029 & 0,033 & $-0,124$ & 0,109 & 0,157 & 0,171 & 0,643 & 0,576 \\
\hline
\end{tabular}

Dan berikut merupakan vektor ciri dari hasil uji principal component analysis.

\section{Menghitung skor komponen utama dari vektor ciri}

Langkah selanjutnya dalam analisis regresi komponen utama yaitu menghitung skor komponen utama dengan menggunakan nilai vektor ciri yang telah diketahui dari langkah sebelumnya. Untuk mencari skor komponen utama kita dapat menggunakan bantuan minitab.

\section{Regresi peubah respon (Y) dengan komponen utama terpilih $(\mathrm{W})$}

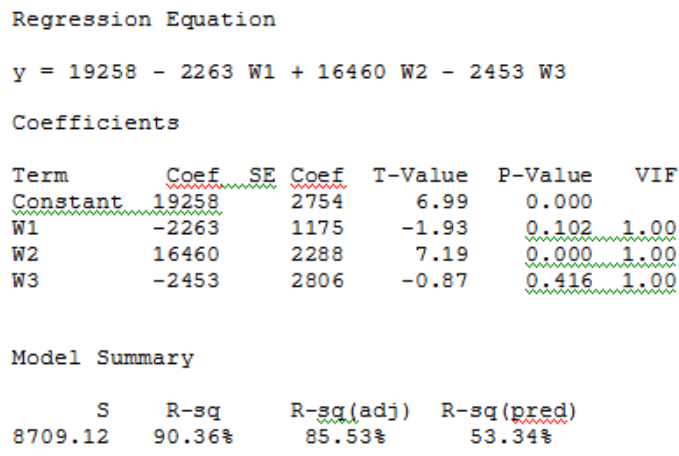

Selanjutnya dengan menggunakan metode kuadrat terkecil diperoleh persamaan regresi komponen utama sebagai berikut :

Dari analisis di atas dapat dilihat bahwa VIF bernilai 1 menunjukan tidak ada korelasi antar variabel komponen utama. Sehingga diperoleh persamaan regresi :

$$
\begin{aligned}
Y= & 19258-2263 a W 1+16460 W 2 \\
& -2453 W 3
\end{aligned}
$$

\section{Transformasi balik peubah baku $Z$ menjadi X}

Substitusikan persamaan W1, W2, W3 dalam persamaan regresi di atas, sehingga : 
$0,253 Z 9+0,116 Z 10)-2453(-0,046 Z 1-0,351$ $Z 2+0,079 Z 3-0,559 Z 4-0,222 Z 5+0,102 Z 6$ $+0,089 Z 7-0,624 Z 8+0,312 Z 9+0,029 Z 10)$

Maka diperoleh persamaan regresi sebagai berikut :

$Y=19258+478,965 Z 1-7413,385 Z 2-$ $813,017 \mathrm{Z3}-7628,253 \mathrm{Z4}+3721,639 \mathrm{Z5}+$ $1329,435 Z 6+157,481 Z 7+10934,264 Z 8-$ $5662,928 Z 9+937,549 Z 10$

Karena persamaan regresi tersebut masih dalam bentuk data yang dibakukan, maka persamaan harus diubah kembali menjadi persamaan dengan variabel asal sebagai berikut :

$$
\begin{aligned}
Y= & 19258+478,965\left(\frac{X_{1}-575856,4}{71070,99649}\right)- \\
& 7413,385\left(\frac{X_{2}-22683,5}{7976,56}\right)-813,017 \\
& \left(\frac{X_{3}-121595,5}{12555,54}\right)-7628,253\left(\frac{X_{4}-40540,1}{19787,22}\right) \\
& +3721,639\left(\frac{X_{5}-50372362}{30177067}\right)+1329,435 \\
& \left(\frac{X_{6}-52295310}{24775452}\right)+157,481\left(\frac{X_{7}-457822}{246666,8}\right) \\
& +10934,264\left(\frac{X_{8}-24036227}{21740379}\right)-5662,928 \\
& \left(\frac{X_{9}-10494,2}{1740,405}\right)+937,549\left(\frac{X_{10}-2286052}{87674,85}\right)
\end{aligned}
$$

Sehingga model akhir persamaan yang di peroleh adalah sebagai berikut :

$$
\begin{aligned}
\hat{Y}= & 48258,1804+0,006739247 X 1- \\
& 0,92939626 X 2-0,06475365 X 3- \\
& 0,38551398 X 4+0,0001233267 X 5+ \\
& 5,365936 X 6+0,0006384361 X 7+ \\
& 0,0005029473 X 8-3,25379897 X 9+ \\
& 0,01069348 \times 10
\end{aligned}
$$

Dari model tersebut dapat kita lihat bahwa variabel $\mathrm{Y}$ dapat diterangkan oleh regresi skor komponen utama terpilih sebesar 90,36\% dan sisanya dterangkan oleh variabel lain diluar model. Berdasarkan pemilihan model dari persamaan $\mathrm{W} 1, \mathrm{~W} 2$, dan $\mathrm{W} 3$ dengan keragaman data $87,9 \%$ maka faktor dominan yang mempengaruhi impor beras di Sulawesi Utara yaitu: produksi beras di SULUT, stok beras di SULUT dan luas panen padi di SULUT.

\section{Uji keberartian model regresi komponen utama}

Keberartian model regresi komponen utama dapat diuji dengan hipotesis uji sebagai berikut :

$\mathrm{H}_{0}: \partial_{\mathrm{k}}=0$ (semua variabel tidak mempengaruhi impor beras di SULUT)

$\mathrm{H}_{1}: \partial_{\mathrm{k}} \neq 0$ (minimal ada satu variabel yang mempengaruhi impor beras di SULUT)

Tabel 3. ANOVA

\begin{tabular}{|l|l|l|l|}
\hline $\begin{array}{c}\text { Sumber } \\
\text { Variasi }\end{array}$ & Df & \multicolumn{1}{c|}{ SS } & \multicolumn{1}{c|}{ MS } \\
\hline Regresi & 3 & 4263343027 & 1421114342 \\
\hline Error & 6 & 455092287 & 75848715 \\
\hline Total & 9 & 4718435314 & \\
\hline
\end{tabular}

$$
\begin{gathered}
\text { Fhitung }=\frac{M S \text { (regresi })}{M S(\text { error })}=\frac{1421114342}{75848715} \\
=18,736169
\end{gathered}
$$

Ftabel $=5,143$

Fhitung $>$ Ftabel $=18,736169>5,143$ maka tolak $\mathrm{H}_{0}$ atau berarti minimal ada satu variabel yang mempengaruhi impor beras di SULUT.

\section{Analisis signifikansi koefisien regresi komponen utama}

Uji signifikansi koefisien terhadap masing-masing variabel baku dilakukan untuk melihat terdapat pengaruh atau tidak dari masing-masing variabel baku.

Tentukan nilai $\mathrm{S}^{*^{2}}$ terlebih dahulu menggunakan rumus :

$$
\begin{aligned}
S^{* 2}=\frac{S^{2}}{\sum(y-\bar{y})^{2}} & =\frac{75848715}{4718435314} \\
& =0,0160749719
\end{aligned}
$$

Selanjutnya akan diperoleh ragam koefisien regresi utama dengan rumus :

$$
\begin{gathered}
\operatorname{Var}\left(\gamma_{n}\right)=S^{* 2} \sum_{g=1}^{m} \frac{\alpha_{i j}}{\lambda_{i}} ; i=1,2, \ldots, p ; j \\
=1,2, \ldots, m
\end{gathered}
$$

karena komponen utama yang terlibat dalam regresi komponen utama pertama ada tiga komponen utama, jadi $m=3$. Dengan demikian diperoleh :

$\operatorname{Var}\left(\gamma_{n}\right)=S^{* 2}\left(\frac{\left(\alpha_{1 j}\right)^{2}}{\lambda_{1}}+\frac{\left(\alpha_{2 j}\right)^{2}}{\lambda_{2}}+\frac{\left(\alpha_{3 j}\right)^{2}}{\lambda_{3}}\right)$

dimana $\mathrm{i}=1,2,3$ dan $\alpha_{i j}$ adalah koefisien komponen utama (vektor ciri), $\lambda$ adalah akar ciri, sehingga dapat ditentukan ragam (varians) dari koefisien regresi $\gamma_{n}, n=$ $1,2,3, \ldots, 10$. 
Tabel 4. Analisis signifikansi koefisien regresi komponen utama

\begin{tabular}{|c|c|r|c|}
\hline $\begin{array}{c}\text { Peubah } \\
\text { Zi }\end{array}$ & $\begin{array}{c}\text { Koefisien } \\
\text { (Yi) }\end{array}$ & $\begin{array}{c}\text { Simpangan } \\
\text { Baku } \\
\text { S(Yi) }\end{array}$ & t-hitung \\
\hline Z1 & 478.965 & 0.02218 & 21594.45 \\
\hline Z2 & -7413.39 & 0.064873 & -114275.35 \\
\hline Z3 & -813.017 & 0.018628 & -43644.889 \\
\hline Z4 & -7628.25 & 0.08694 & -87741.58 \\
\hline Z5 & 3721.639 & 0.040512 & 91865.1017 \\
\hline Z6 & 1329.435 & 0.028065 & 473699.855 \\
\hline Z7 & 157.481 & 0.024226 & 6500.49534 \\
\hline Z8 & 10934.26 & 0.095257 & 114786.987 \\
\hline Z9 & -5662.93 & 0.048766 & -116124.51 \\
\hline Z10 & 937.549 & 0.02375 & 39475.7474 \\
\hline
\end{tabular}

Nilai t-tabel=2,262 dengan derajat bebas (9), karena $\mid \mathrm{t}$-hitung $\mid$ seluruh koefisien > t-tabel maka dapat disimpulkan koefisien masing-masing variabel signifikan. Sehingga disimpulkan semua variabel mempengaruhi impor beras di SULUT.

\section{KESIMPULAN DAN SARAN}

\section{Kesimpulan}

1. Analisis regresi komponen utama dapat mengatasi masalah multikolinearitas pada data impor beras di Sulawesi Utara. Ini terlihat dimana nilai VIF pada regresi komponen utama bernilai satu untuk semua variabel komponen utama.

2. Model penduga yang diperoleh $\hat{Y}=$ $48258,1804+0,006739247 X_{1}-$ $0,92939626 X_{2}-0,06475365 X_{3}-$ $0,38551398 X_{4}+0,0001233267 X_{5}+$ $5,365936 X_{6}+0,0006384361 X_{7}+$ $0,0005029473 X_{8}-3,25379897 X_{9}+$ $0,01069348 \quad X_{10}, \quad$ nilai koefisien determinasi $\left(\mathrm{R}^{2}\right)=90,36 \%$ dan nilai $\left(\mathrm{R}_{\mathrm{adj}}\right)=85,53 \%$.

3. Semua variabel yaitu Produksi beras Sulawesi Utara $\left(X_{1}\right)$, stok beras di Sulawesi Utara $\left(X_{2}\right)$, luas panen padi Sulawesi utara $\left(X_{3}\right)$, penerimaan beras dari dalam negeri sulawesi utara $\left(X_{4}\right)$, devisa impor paid pada bea dan cukai Bitung $\left(X_{5}\right)$, produk domestik regional bruto atas dasar harga berlaku menurut lapangan usaha di Sulawesi Utara $\left(X_{6}\right)$, pendapatan pajak daerah Sulawesi Utara
$\left(X_{7}\right)$, penggunaan devisa impor unpaid pada bea dan cukai Bitung $\left(X_{8}\right)$, kurs $\left(X_{9}\right)$, dan jumlah penduduk Sulawesi Utara $\left(X_{10}\right)$ mempengaruhi impor beras di SULUT (Y).

\section{Saran}

Dalam menangani multikolinearitas peneliti hanya menggunakan metode analisis regresi komponen utama. Dan untuk penelitian selanjutnya mungkin dapat menggunakan metode-metode lain dalam menangani multikolinearitas agar bisa dibandingkan hasilnya.

\section{DAFTAR PUSTAKA}

Antono, H. T., M. Lutfi. 2014. VariabelVariabel yang Berpengaruh Terhadap Swabakar Batubara Menggunakan Regresi Komponen Utama. Jurnal Statistika. 14(1) : 25-30.

Mariana. 2013. Analisis Komponen Utama. Jurnal Matematika dan Pembelajarannya. 2(2) : 112-113.

Morrison, D. F. 1978. Multivariate Statistical Methods Series in Probability and Statistics. Mc Graw Hill. Singapore.

Ryan, T. P. 1997. Modern Regression Methods. John Wiley \& Sons. New York.

Sembiring, R. K. 1995. Analisis Regresi. ITB. Bandung.

Suryanto. 1988. Metode Statistik Multivariat I. P2LPTK. Jakarta.

Wohon, S. C., D. Hatidja., dan N. Nainggolan. 2017. Penentuan Model Regresi Terbaik Menggunakan Metode Stepwise. Jurnal Ilmiah Sains.17(2) : 1-9. 